\title{
Guidelines
}

\section{Clube Português do Pâncreas Recommendations for Chronic Pancreatitis: Etiology, Natural History, and Diagnosis (Part I)}

\author{
Eduardo Rodrigues-Pinto $^{a} \quad$ Ana Caldeira $^{b}$ João Bruno Soares ${ }^{c}$ \\ Teresa Antunes $^{d}$ Joana Rita Carvalho ${ }^{d}$ José Costa-Maia ${ }^{e}$ Pedro Oliveira ${ }^{f}$ \\ Richard Azevedo $^{b}$ Rodrigo Liberal ${ }^{a}$ Tiago Bouça Machado ${ }^{\mathrm{e}}$ \\ Vitor Magno-Pereira9 Pedro Moutinho-Ribeiro ${ }^{a}$ \\ ${ }^{a}$ Gastroenterology Department, Centro Hospitalar de São João, Porto, Portugal; b Gastroenterology Department, \\ Hospital Amato Lusitano, Castelo Branco, Portugal; ' CGastroenterology Department, Hospital de Braga, Braga, \\ Portugal; ${ }^{d}$ Gastroenterology Department, Hospital de Santa Maria, Centro Hospitalar Lisboa Norte, Lisbon, Portugal;

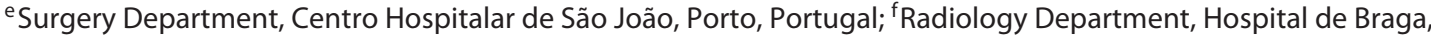 \\ Braga, Portugal; ${ }^{9}$ Gastroenterology Department, Hospital Central do Funchal, Funchal, Portugal
}

\section{Keywords}

Chronic pancreatitis · Physiopathology · Clinical

presentation $\cdot$ Natural history $\cdot$ Diagnosis

\section{Abstract}

Chronic pancreatitis (CP) is a heterogeneous disease, with different causes and often a long delay between onset and full classic presentation. Clinical presentation depends on the stage of the disease. In earlier stages, recurrent episodes of acute pancreatitis are the major signs dominating clinical presentation. As the inflammatory process goes on, less acute episodes occur, and pain adopts different aspects or may even disappear. After 10-15 years from onset, functional insufficiency occurs. Then, a classic presentation with pain and pancreatic exocrine and endocrine insufficiency appears. Diagnosis remains challenging in the early stages of the disease, as its initial presentation is usually ill-defined and overlaps with other digestive disorders. Computed tomography and magnetic resonance cholangiopancreatography should be the first choice in patients with suspected $\mathrm{CP}$. If the results are normal or equivocal but still there is a

\section{KARGER}

E-Mail karger@karger.com www.karger.com/pjg (c) 2019 Sociedade Portuguesa de Gastrenterologia Published by S. Karger AG, Basel

Karger

Open access

This article is licensed under the Creative Commons AttributionNonCommercial-NoDerivatives 4.0 International License (CC BYNC-ND) (http://www.karger.com/Services/OpenAccessLicense). Usage and distribution for commercial purposes as well as any distribution of modified material requires written permission. high suspicion of $\mathrm{CP}$, the next option should be endoscopic ultrasound. Endoscopic retrograde cholangiopancreatography is mainly a therapeutic technique, and for the diagnostic purpose should only be used when all other imaging modalities and pancreatic function tests have been exhausted. Indirect tests are used to quantify the degree of insufficiency in already-established late CP. Recommendations on CP were developed by Clube Português do Pâncreas (CPP), based on literature review to answer predefined topics, subsequently discussed and approved by all members of CPP. Recommendations are separated in two parts: "chronic pancreatitis etiology, natural history, and diagnosis," and "chronic pancreatitis medical, endoscopic, and surgical treatment." This abstract pertains to part I.

(C) 2019 Sociedade Portuguesa de Gastrenterologia Published by S. Karger AG, Basel

This is part I of the Clube Português do Pâncreas Recommendations for Chronic Pancreatitis. For part II, see GE Port J Gastroenterol 2019, Doi 10.1159/000497389.
Pedro Moutinho-Ribeiro, MD

Gastroenterology Department, Centro Hospitalar São João

Al. Prof. Hernâni Monteiro

PT-4200-319 Porto (Portugal)

E-Mail pmoutinhoribeiro@gmail.com 
Recomendações do Clube Português do Pâncreas sobre Pancreatite Crónica: Etiologia, História Natural e Diagnóstico (Parte I)

\section{Palavras-Chave}

Pancreatite crónica · Fisiopatologia · Apresentação

clínica $\cdot$ História natural $\cdot$ Diagnóstico

\section{Resumo}

A pancreatite crónica $(\mathrm{PC})$ é uma doença heterogénea, com diferentes etiologias, muitas vezes, com um longo período entre o início de sintomatologia e a apresentação clínica clássica. A clínica depende do estadio da doença, sendo que nos estadios iniciais, predominam episódios recorrentes de pancreatite aguda; com a progressão da doença, os episódios agudos tornam-se menos frequentes, e a dor adota padrões diferentes, podendo inclusive desaparecer; a insuficiência funcional desenvolve-se $10 \mathrm{a}$ 15 anos após o início, assumindo-se então, a apresentação clássica com dor, insuficiência pancreática exócrina e endócrina. O diagnóstico pode ser desafiador nos estadios iniciais da doença, já que a apresentação inicial é geralmente mal definida e se sobrepõe a outros patologias gastrointestinais. A TAC e CPRM devem ser os primeiros métodos de imagem em doentes com suspeita de PC. Se os resultados forem normais ou ambíguos, a próxima opção deve ser a ecoendoscopia. A CPRE é uma técnica principalmente terapêutica, sendo que para fins de diagnóstico, deve ser reservada para quando todas os outros exames de imagem/testes de função pancreática forem inconclusivos. Testes indiretos de função pancreática devem ser usados para quantificação do grau de insuficiência pancreática em doentes com PC já estabelecida. As recomendações sobre PC foram desenvolvidas pelo Clube Português do Pâncreas (CPP), com base numa revisão da literatura para responder a questões predefinidas, posteriormente discutidos e aprovados por todos os membros do CPP. As recomendações encontram-se separadas em duas partes: "etiologia da pancreatite crónica, história natural e diagnóstico" e "tratamento médico, endoscópico e cirúrgico da pancreatite crónica." Este resumo corresponde à parte I. @ 2019 Sociedade Portuguesa de Gastrenterologia Publicado por S. Karger AG, Basel

\section{Introduction}

Chronic pancreatitis $(\mathrm{CP})$ is an inflammatory disease that causes progressive and irreversible damage to the parenchyma of the organ, leading to progressive scarring of the pancreatic tissue with consequent loss of function. Recent studies point to an increasing incidence of $\mathrm{CP}$ over the past decade, which probably reflects an improvement in diagnosis and changes in disease definition $[1,2]$. The reported annual incidence, roughly similar in all countries, ranges from 5 to 14 cases per 100,000 individuals $[1,3-5]$ with a prevalence of approximately $30-50$ per 100,000 individuals, being 5 times more frequent in men than in women [6].

The pathophysiology of CP is fairly complex and incompletely understood [4]. Pancreatic stellate cells, responsible for secretion of excessive amounts of extracellular matrix proteins, play a major role in pancreatic injury $[7,8]$. CP is a heterogeneous disease, with different causes and often a long delay between the onset and full classic presentation. Functional consequences include recurrent or constant abdominal pain, diabetes mellitus (DM) (endocrine insufficiency), and maldigestion (exocrine insufficiency) with consequent malnutrition. Diagnosis remains challenging in the early stages of the disease, as its initial presentation is usually ill-defined and overlaps with other digestive disorders. On the other hand, later stages may present with calcification of the pancreatic parenchyma, anatomic changes of the pancreatic ducts, associated collections, vascular complications, and bile duct or duodenal lumen obstruction.

The aims of treatment include lifestyle modifications, nutrition, exocrine and endocrine pancreatic insufficiencies correction, and pain management. Other therapeutic options comprise endoscopic and surgical interventions.

This paper refers to part I of Clube Português do Pâncreas (CPP) recommendations for CP management. The recommendations were initially based on literature review to answer predefined topics, subsequently discussed and approved by all members of CPP.

\section{Etiology and Risk Factors}

Both genetic and environmental factors have been associated with CP [7]. The TIGAR-O classification proposes risk modifiers that may interact with each other to produce CP [9] (Table 1).

The association between alcohol and smoking and $\mathrm{CP}$ is dose-dependent $[1,7]$. Chronic alcohol abuse is re- 
Table 1. Etiologies of chronic pancreatitis according to the TIGAR-O system

\begin{tabular}{|c|c|}
\hline Toxic-metabolic & $\begin{array}{l}\text { Alcohol } \\
\text { Tobacco } \\
\text { Hypercalcemia } \\
\text { Hypertriglyceridemia } \\
\text { Chronic kidney disease } \\
\text { Medications }\end{array}$ \\
\hline Idiopathic & $\begin{array}{l}\text { Tropical chronic pancreatitis } \\
\text { Early-onset } \\
\text { Late-onset }\end{array}$ \\
\hline Genetic & $\begin{array}{l}\text { Autosomal dominant: hereditary pancreatitis } \\
\text { PRSS1 mutations } \\
\text { Autosomal recessive/modifier genes } \\
\text { CFTR mutations } \\
\text { SPINK1 mutations } \\
\text { CTRC mutations } \\
\text { Other }\end{array}$ \\
\hline Autoimmune & Type 1 (IgG4-related) and type 2 \\
\hline $\begin{array}{l}\text { Recurrent and } \\
\text { severe acute pan- } \\
\text { creatitis }\end{array}$ & $\begin{array}{l}\text { Postnecrotic (after severe necrotizing } \\
\text { pancreatitis) } \\
\text { Vascular disease/ischemia }\end{array}$ \\
\hline Obstructive & $\begin{array}{l}\text { Pancreas divisum } \\
\text { Sphincter of Oddi disorders } \\
\text { Malignant pancreatic duct obstruction } \\
\text { Posttraumatic pancreatic duct scars and } \\
\text { strictures }\end{array}$ \\
\hline
\end{tabular}

CFTR, cystic fibrosis transmembrane conductance regulator; CTRC, chymotrypsin C; PRSS1, cationic trypsinogen; SPINK1, serine protease inhibitor Kazal type 1 .

sponsible for $40-70 \%$ of $\mathrm{CP}$ cases in western countries [1]. Although at least $60-80 \mathrm{~g}$ of ethanol/day during 5-10 years is required for CP development $[1,3]$, less than $10 \%$ of heavy drinkers develop alcohol-induced pancreatitis [7]. Alcohol sensitizes the pancreas to other external factors, such as smoking and diet, which, along with genetic predisposition, interact to increase alcohol toxicity [7].

Cigarette smoking, apart from being an independent risk factor, also accelerates CP disease course $[7,10]$ and significantly increases the risk of secondary pancreatic cancer and overall mortality [3]. The relative risk of developing $\mathrm{CP}$ is 3 -fold higher in heavy smokers ( $>1$ pack/ day) [4].

Non-alcohol- and non-tobacco-associated CP accounts for $20-50 \%$ of cases in western countries [1]. Hereditary pancreatitis is a rare cause of $\mathrm{CP}$ (prevalence of $0.3 / 1,000,0000$ individuals) [1], and only mutations in the PRSS1 gene (which encodes trypsin 1) appear sufficient to cause the disease [3]. The inheritance pattern is auto- somal dominant with an incomplete penetrance (80\%). All other identified mutations and polymorphisms should be considered as cofactors or modifiers that increase the severity of disease [3]. Mutations in SPINK1 and CTRC (involved in controlling intrapancreatic trypsin 1 activity) are strongly associated with recurrent acute and CP. Mutations in the CFTR genes are also commonly identified.

Autoimmune pancreatitis (AIP) represents $2-4 \%$ of cases of CP and encompasses two different chronic entities [11]. In type 1 AIP, patients are usually older, with a mean age at disease onset of 60-70 years [4, 7]. Involvement of other organs occurs in about $60 \%$ of patients (biliary strictures, retroperitoneal fibrosis, pseudotumors, and sialoadenitis). Many of the plasma cells and CD4+ T cells that infiltrate the pancreas express IgG4 on their surface and elevation in serum levels of IgG4 can be found in about $2 / 3$ of patients [4]. Type 2 AIP, less frequent than type 1 and typically occurring in younger patients $(40-50$ years) [7], is limited to the pancreas and is not associated with an infiltration of IgG4+ cells [11].

Idiopathic CP represents $10-30 \%$ of $\mathrm{CP}$ cases [7] and is more common in women [4]. Interpreting idiopathic $\mathrm{CP}$ literature is difficult, as many patients are probably mislabeled, with possible contributions of less severe CFTR and SPINK1 gene mutations. Idiopathic CP can present in two different forms: an early onset type (appearing in the late second or third decade of life) and a late-onset form (in the sixth or seventh decade) [4]. Tropical pancreatitis, also known as fibrocalculous pancreatic diabetes, is a form of idiopathic early-onset pancreatitis mainly reported in developing countries [11].

Obstruction of the main pancreatic duct (benign or malignant causes) can also lead to CP [4]. Acquired strictures can occur after severe attacks of acute pancreatitis, trauma, duodenal wall cysts, sphincter of Oddi dysfunction [9], or as a consequence of tumor obstruction (adenocarcinoma, islet cell tumor, intraductal papillary mucinous neoplasms or ampullary neoplasms) [4]. Pancreas divisum, a common normal variant, is rarely considered a cause of CP [4]. Many patients with pancreas divisum often have coexistent genetic mutations that may contribute to CP [3].

Recurrent episodes of acute pancreatitis may also lead to the development of a chronic inflammatory response, culminating in CP. This can also occur even with just one severe attack of acute pancreatitis, usually associated with significant pancreatic necrosis and the need for surgical necrosectomy [4]. 
CP natural history can be divided into an early phase (first 5 years of disease, characterized by acute pancreatitis episodes, pain, and hospitalizations), a middle phase (from 5 to 10 years, characterized by less acute manifestations, while morphological changes become evident), and a late phase (from approximately 10 years onwards, with acute manifestations becoming rare and symptoms of endocrine and exocrine insufficiency emerging) [12]. The progression and duration of each phase is highly variable and dependent on the etiologic factors of CP. Furthermore, the sequence of events can occur in all possible manners.

Prognosis of CP is variable and largely depends on the presence of ongoing alcohol consumption and associated cigarette smoking. Sustained alcohol intake increases mortality risk by an additional $60 \%$ [4]. The risk of pancreatic cancer in patients with chronic alcoholic pancreatitis at 10 and 20 years is 1.8 and $4 \%$, respectively. The cumulative proportion of patients with pancreatic cancer in this population 20 years after CP diagnosis is $4 \%$ [1]. Concerning hereditary $\mathrm{CP}$, the cumulative proportion of patients with pancreatic cancer is $1.5 \%$ at 20 years, $8.5 \%$ at 40 years, and $25 \%$ at 60 years after symptom onset [1]. The cause of death in patients with CP is usually related to other medical conditions associated with smoking, alcohol abuse, pancreatic cancer, and postoperative complications rather than CP itself [4]. Ten-year and 20-year survival rates in patients with $\mathrm{CP}$ are approximately 70 and $45 \%$, respectively [4].

\section{Diagnosis}

\section{Statement}

Computed tomography (CT), magnetic resonance cholangiopancreatography (MRCP), and endoscopic retrograde cholangiopancreatography (ERCP) all have comparable high diagnostic accuracy in the initial diagnosis of CP [13]; endoscopic ultrasound (EUS) and ERCP outperform the other imaging techniques, while transabdominal ultrasound is the least accurate. As diagnostic sensitivity of $\mathrm{CT}$ and MRCP is not significantly lower than that of ERCP and EUS, and specificity is comparable, these noninvasive modalities are a likely first choice in patients with suspected CP. If the results are normal or equivocal but still there is a high suspicion of $\mathrm{CP}$, the next choice should be EUS mainly due to its high accuracy in general and for early $\mathrm{CP}$ in particular. Due to its invasiveness and risks, ERCP 
Fig. 1. Algorithm approach to diagnosis of chronic pancreatitis.
Clinical history, physical exam, routine lab tests, consider indirect (noninvasive) pancreatic function testing

Computed tomography scan and/or magnetic resonance imaging with cholangiopancreatography \pm secretin

Chronic pancreatitis diagnostic criteria: Cambridge grade 3 or 4

If results are equivocal, proceed to the next step

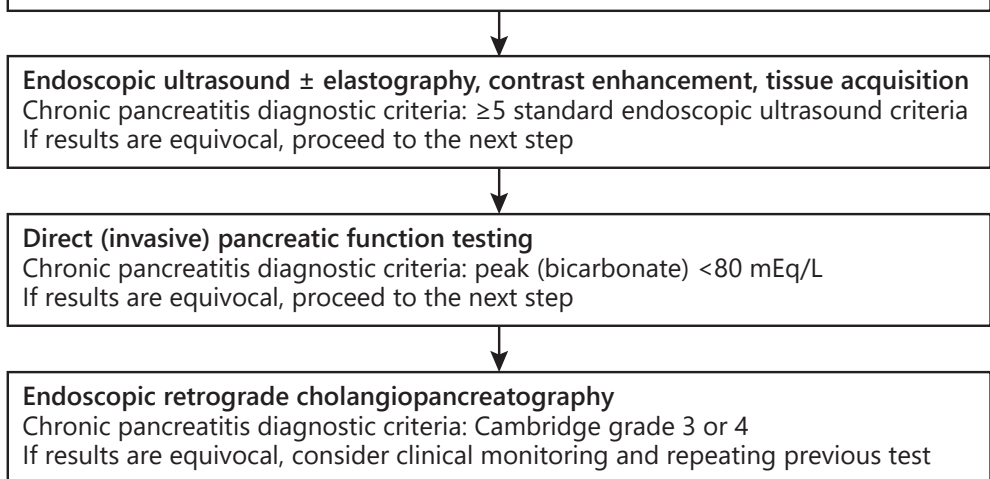

plasma levels of high-density lipoprotein C and A (atherogenesis protectors) [22]. As a result of exocrine insufficiency, weight loss is expected anytime. Nutritional status evaluation is of major importance and helps to assess the impact of PEI in patients not only by the time of diagnosis but also monitoring disease development and the efficacy of treatment.

Overt DM usually occurs late in CP. Around 60-75\% of CP patients and up to $90 \%$ of calcifying CP patients have DM, and those with alcohol intake will develop insulin insufficiency earlier [15]. DM may also be the first manifestation of painless forms of pancreatitis (20\%) [23]. As fibrosis increases, islet cell injury with beta-cell mass reduction leads to impairment of insulin secretion [24]. As type $1 \mathrm{DM}, \mathrm{CP}$-related diabetes (type 3) usually requires insulin therapy. However, the major difference between them is the simultaneous decrease in alpha cells that occurs in type $3 \mathrm{DM}$, leading to glucagon impairment and, therefore, increased risk of hypoglycemia, both spontaneous and treatment related $[25,26]$. Type 3 DM has the same diagnostic criteria as type 1 or 2: fasting plasma glucose $\geq 126 \mathrm{mg} / \mathrm{dL}$ (at least $8 \mathrm{~h}$ fasting), oral glucose tolerance test at $2 \mathrm{~h} \geq 200 \mathrm{mg} / \mathrm{dL}$ or $\mathrm{HbAlc}$ $\geq 6.5 \%$. Treatment with insulin is the standard of care, even though metformin may sometimes be used as a first approach in patients with a high ratio insulin/C-peptide, $\mathrm{HbAlc} \leq 7 \%$, high body mass index, and family history of DM.

\section{Functional Tests}

PEI can be defined as an inadequate pancreatic enzyme activity due to insufficient enzyme production, insufficient enzyme activation, or early enzyme degradation. In order to assess pancreatic function, direct and indirect methods exist. In cases of CP clinical suspicion, a functional evaluation should be performed because even mild-to-moderate PEI ("compensated PEI") can disturb the digestive process and lead to deficiencies of several nutrients and clinical implications [20]. Direct tests estimate the products released in pancreatic secretion (bicarbonate and enzymes), while indirect tests evaluate the pancreatic function through the presence or quantification of pancreatic enzymes in serum and stool or by the presence of labelled carbon dioxide $\left(\mathrm{CO}_{2}\right)$ in exhaled air [20].

Even though the direct test secretin-pancreozymin test is considered the gold standard for diagnosis of PEI (sensitivity and specificity $>90 \%$ ), it has been progressively abandoned, as it is an invasive, time consuming, nonstandardized, and expensive method [27]. The endoscopic secretin/pancreatic function test is a variant of the previous secretin test, avoiding problems associated with the standard test, having also a high sensitivity for detecting PEI [28].

Compared to direct tests, indirect tests of pancreatic exocrine function are less sensitive and specific but cheap- 
er and easier to administer [29]. The basis of indirect tests is to detect alterations due to loss of pancreatic exocrine function. They are best used to quantify the degree of insufficiency in already-established late CP [30] and generally should be accompanied by cross-sectional CT or magnetic resonance imaging to rule out malignancy [31].

Urine tests are rarely used as they have been replaced by the FE and direct tests which have better specificity and sensitivity [29]. Blood tests to evaluate PEI consist of the measurement of serum immunoreactive trypsinogen [29] and have been validated for PEI assessment in the context of cystic fibrosis [32].

\section{Stool Tests}

Although the 3-day fecal fat test is considered the gold standard to diagnose steatorrhea (92\% of sensibility), it has only $42 \%$ specificity for PEI, as it does not distinguish between pancreatic and nonpancreatic causes of PEI [33].

Elastase is a pancreatic-specific protease, which is not degraded by the intestine, and has a 5-6 times higher concentration in stool compared to pancreatic secretion [34]. A low FE concentration of $<200 \mu \mathrm{g} / \mathrm{g}$ suggests PEI, whereas $<100 \mu \mathrm{g} / \mathrm{g}$ suggests severe PEI [30]. Classic false-positive FE measurements (low levels) occur in small bowel bacterial overgrowth and watery stool. Classic false-negative serum trypsin measurements (normal/high levels) occur when performed in the setting of acute pancreatic inflammation [31]. Its sensitivity and specificity range, respectively, from 0 to $63 \%$ and 80 to $95 \%$ in mild-tomoderate PEI and from 77 to $100 \%$ and 76 to $100 \%$ in moderate-to-severe PEI [35]. Fecal chymotrypsin is no longer employed because the FE test has more sensitivity and specificity [29].

Microscopic examination of stools for fat droplets works just as a screening test that can be performed before additional tests, in order to detect fat globules.

\section{Breath Tests}

Radiolabeled carbon breath tests samples are taken before and after a test meal containing ${ }^{13} \mathrm{C}$-labeled substrate. The most widely used test is the ${ }^{13} \mathrm{C}$-labeled mixed triglyceride breath test [25]. It involves the ingestion of $250 \mathrm{mg}$ of 2-octanoyl (1-13C)-1.3 distearoyl glycerol (Euriso-top, Saint-Aubin, France) with $16 \mathrm{~g}$ of fat. This substrate is digested by lipase, releasing ${ }^{13} \mathrm{C}$-labeled octanoic acid, which is then absorbed and metabolized to form ${ }^{13} \mathrm{CO}_{2}$, ultimately released in expired breath. Breath samples are collected at $15 \mathrm{~min}$ intervals for $6 \mathrm{~h}$ [36]. It might be an accurate and alternative method to the quantitative fecal fat test to assess the effect of enzyme therapy

CPP Recommendations for Chronic Pancreatitis: Part I on fat digestion and the correction of fat malabsorption during therapy [29]. Its limitations are its poor sensibility in the absence of steatorrhea and inability to differentiate between pancreatic and nonpancreatic causes of fat malabsorption [29].

\section{Imaging Modalities}

Imaging modalities are indispensable for the diagnosis of CP and its complications. Diagnosis of CP by imaging modalities relies on changes in morphology of the pancreas, easily detected in advanced $\mathrm{CP}$, but hardly recognized in early disease $[31,37,38]$.

\section{Computed Tomography}

The classical CT findings in CP are dilatation of the pancreatic duct, pancreatic calcifications, and parenchymal atrophy. The main pancreatic duct is classically beaded and irregular; however, the main duct may also be regularly contoured. CT is considered the most appropriate method for identifying pancreatic calcifications. Nevertheless, very small calcifications may be obscured by pancreatic parenchymal contrast enhancement, and thus pancreatic CT should include a non-contrast-enhanced phase. Additionally, while pancreatic atrophy is visualized in a large proportion of patients with $\mathrm{CP}$, this is not a specific finding and can also be seen with normal aging.

CT is especially helpful in identifying complications of $\mathrm{CP}$, including pseudocysts, portosplenic venous thrombosis, collaterals and arterial pseudoaneurysms, and pancreatico-pleural fistulas $[31,37,38]$. CT may also be useful in the differential diagnosis between mass-forming pancreatitis and pancreatic cancer [20]. Features that favor $\mathrm{CP}$ are intraductal or parenchymal calcifications, lack of obstructing mass, irregular dilatation of the pancreatic duct, and relatively limited atrophy of the gland. The presence of a "duct-penetrating" sign (dilated duct or branches which penetrate an apparent mass) favors CP. Features favoring cancer include pancreatic duct dilatation with associated mass at the site of obstruction, atrophy of the pancreas, vascular invasion, and metastases. $\mathrm{CT}$ is considered by many as the best initial imaging test in the workup for CP since it is widely accessible, allows for comprehensive detailed evaluation of the pancreas, and it is especially useful in detecting changes seen in advanced disease and complications of CP. Moreover, it can quickly assess extrapancreatic pathology that may explain various presentations mimicking CP. It has, however, two important limitations, namely the evaluation of pancre- 
Table 2. Cambridge classification for transabdominal ultrasound (US), computed tomography (CT), magnetic resonance imaging with cholangiopancreatography (MRCP) and endoscopic retrograde cholangiopancreatography (ERCP) findings in chronic pancreatitis

\begin{tabular}{|c|c|c|c|}
\hline Grade & US & CT/MRCP & ERCP \\
\hline 0 & $\begin{array}{l}\text { Normal organ, duct }<2 \mathrm{~mm} \text {, regular } \\
\text { contour }\end{array}$ & None & $\begin{array}{l}\text { No pathological alterations } \\
\text { on good visualization of } \\
\text { pancreatic duct system }\end{array}$ \\
\hline 1 & $\begin{array}{l}\text { Echo-dense gland contour, gland } \\
\text { enlarged (up to } 1.5 \text {-fold), } \\
\text { duct }<3 \mathrm{~mm} \text {, lobular honeycomb } \\
\text { appearance }\end{array}$ & $\begin{array}{l}\text { Not possible to demarcate duct system on CT/ } \\
\text { MRCP using current methods }\end{array}$ & $\begin{array}{l}<3 \text { abnormal side branches, } \\
\text { main duct normal }\end{array}$ \\
\hline 2 & $\begin{array}{l}\text { Contour irregularities, irregular hyper- } \\
\text { echoic main pancreatic duct }>3 \mathrm{~mm} \text {, } \\
\text { lobular texture with echo-dense septa- } \\
\text { tions }\end{array}$ & $\begin{array}{l}\geq 2 \text { of the following changes: pancreatic duct } \\
\text { between } 2 \text { and } 4 \text { mm in the pancreatic body; } \\
\text { mild pancreatic enlargement; heterogeneous } \\
\text { parenchymal structure; small cystic changes } \\
(<10 \mathrm{~mm}) \text {; duct irregularities; pathological side } \\
\text { branches }>3\end{array}$ & $\begin{array}{l}>3 \text { abnormal side branches, } \\
\text { main duct normal }\end{array}$ \\
\hline 4 & $\begin{array}{l}\text { As in } 3 \text {, plus duct stones, duct obstruc- } \\
\text { tion, tumorous enlargement of the } \\
\text { gland }>2 \text {-fold, splenic vein thrombosis }\end{array}$ & $\begin{array}{l}\text { One of the changes named under } 2 \text { or } 3 \text { plus } \\
\geq 1 \text { of the following: cystic structures }>10 \mathrm{~mm} \text {; } \\
\text { parenchymal calcifications; intraductal filling } \\
\text { defects (calcifications); duct obstruction } \\
\text { (strictures); major duct irregularities }\end{array}$ & $\begin{array}{l}\text { As in } 3 \text {, plus cysts, duct } \\
\text { calculi, duct obstruction } \\
\text { (stricture), involvement of } \\
\text { adjacent organs }\end{array}$ \\
\hline
\end{tabular}

Cambridge grades 3 and 4 are considered diagnostic of chronic pancreatitis.

atic ductal anatomy and the initial parenchymal changes for CP early diagnosis; it also poses the risk of radiation.

\section{Magnetic Resonance Imaging with}

Cholangiopancreatography

MRCP is highly sensitive and specific in diagnosing $\mathrm{CP}$ by evaluating both parenchymal and ductal changes, especially in patients with more advanced CP $[31,37,38]$. Parenchymal changes that are visualized include pancreatic atrophy, depressed $\mathrm{T} 1$ signal, irregular contour of head or body, heterogeneous parenchyma, and delayed enhancement of the pancreas after gadolinium administration. Ductal changes include intraductal filling defects often indicative of calculi, main pancreatic duct dilation, side branch dilation, and irregular duct contour. While there are no standardized criteria for diagnosing $\mathrm{CP}$ with the use of MRCP, the Cambridge classification for ERCP may be adapted (Table 2) $[31,37,38]$. This classification may also be helpful in interpreting and grading the findings of other imaging modalities, namely transabdominal ultrasound and CT.
Secretin-enhanced MRCP has been shown to ameliorate sensitivity in early $\mathrm{CP}[39,40]$. Besides enhancing visualization of the main pancreatic duct and abnormal side branches compared to conventional MRCP (increasing the overall sensitivity for the detection of ductal changes of CP) [41], it also estimates exocrine function (through evaluation of pancreatic duct compliance and pancreatic duct flow rate) which correlates well with the severity of pancreatitis [40].

MRCP has a high sensitivity and specificity in the differential diagnosis of pancreatic masses [42]. This is largely based on the same findings described for CT, especially the "duct-penetrating" sign. However, this does not apply when a carcinoma develops in the presence of CP. In this case, like with all imaging modalities, the sensitivity and specificity is significantly reduced and inferior to that documented for EUS-guided tissue acquisition.

\section{Endoscopic Ultrasound}

Due to its superior spatial resolution, EUS is considered the most sensitive imaging technique for the diagno- 
Table 3. Endoscopic ultrasound criteria for chronic pancreatitis and histological correlates (International Working Group in the diagnosis of CP)

\begin{tabular}{llll}
\hline Parenchymal criteria & Histologic correlate & Ductal criteria & Histologic correlate \\
\hline Hyperechoic foci & Focal fibrosis & Main duct dilation $(\mathrm{mm})$ & $>3$ head, $>2$ body, $>1$ tail \\
Hyperechoic strands & Bridging fibrosis & Duct irregularity & Focal dilation/narrowing \\
Lobular contour & Interlobular fibrosis & Hyperechoic margins & Periductal fibrosis \\
Cysts & Cyst/pseudocyst & Visible side branches & Side branch dilation \\
& Calcified stones & Stones & Calcified stones \\
\hline
\end{tabular}

sis of $\mathrm{CP}$, mainly during the early stages of the disease. EUS evaluates both parenchymal and ductal changes of CP. A total of 9 EUS criteria (4 parenchymal and 5 ductal) have been proposed by the International Working Group in the diagnosis of CP (Table 3) [43]. Currently, there is no optimal cut-off for establishing a EUS diagnosis of CP, even though a minimum of 5 criteria are often required $[31,38,39,44]$. The presence of 5 or more findings provides a definitive diagnosis of $\mathrm{CP}$, whereas 2 or less findings effectively rule out this disease. Patients with 3-4 criteria have an indeterminate diagnosis and should be thoroughly worked up further with pancreatic function testing. The 9 criteria have been linked to distinct histological changes noted from specimens collected after EUS evaluation [45]. Given the lack of standardization across EUS interpretation in the context of $\mathrm{CP}$, the Rosemont criteria were developed [46]; however, this classification is more complex and does not improve the diagnostic value of the standard criteria.

Like other imaging modalities, EUS is also able to detect multiple complications of $\mathrm{CP}$, in particular pancreatic cancer. Although there is no clear consensus on whether and how to conduct pancreatic cancer screening in $\mathrm{CP}$, many centers recommend the use of EUS, based on its ability to identify small pancreatic masses, even though this ability is reduced in the presence of CP. EUS-guided tissue acquisition is an essential tool in the differential diagnosis between mass-forming CP and pancreatic cancer [39]. In fact, EUS-guided tissue acquisition is considered the most reliable procedure for detecting pancreatic malignancy in patients with or without $\mathrm{CP}$, although in $\mathrm{CP}$ the sensitivity decreases from $80-95$ to $50-75 \%$ [39]. There is also a probability of false negatives (5-10\%), and thus in patients with suspected operable pancreatic cancer in imaging modalities, surgery is recommended even without prior cytological confirmation. New EUS imaging techniques, such as elastography (E-EUS) and contrast-enhanced harmonic
EUS (CEH-EUS) have also been proposed to increase the accuracy of EUS in the differential diagnosis between mass-forming $\mathrm{CP}$ and pancreatic cancer, not only by allowing better morphological characterization of the mass, but also by directing EUS-guided tissue acquisition. Although two recent meta-analyses $[44,45]$ have demonstrated that CEH-EUS and E-EUS are reliable techniques for the characterization of solid pancreatic masses, most studies were unicentric and included low numbers of patients with CP $[47,48]$. Several computer-aided diagnosis methods for E-EUS and CEH-EUS may reduce various biases and increase the accuracy of EUS in this setting, but their role in the characterization of solid pancreatic lesions in patients with $\mathrm{CP}$ is still unclear.

\section{Endoscopic Retrograde Cholangiopancreatography}

Nowadays, the use of ERCP in the management of CP is typically limited to therapeutic interventions. Historically, specific findings described in $\mathrm{CP}$ by a retrograde pancreatogram obtained during ERCP include the main pancreatic duct caliber and contour, clear definitions of its side branches, intraductal filling defects, strictures, and cavity formation. Although ERCP is sensitive for detection of changes in the pancreatic duct, there are several drawbacks when it is used for the diagnosis of CP. Like EUS, it is operator-dependent and prone to interobserver variability. It does not provide assessment of the classic parenchymal CP changes. Moreover, it is the most invasive diagnostic modality and carries postprocedural risks, most notably, post-ERCP pancreatitis. Finally, other potential confounders to interpretation of pancreatograms include age-related ductal changes and postacute pancreatitis ductal changes which are indistinguishable from ductal changes related to CP. For these reasons, ERCP should be used for diagnosing CP only when all other imaging modalities have been exhausted. 


\section{Conclusion}

$\mathrm{CP}$ is a heterogeneous disease, with different causes and often a long delay between onset and full classic presentation. Clinical presentation depends on the stage of the disease. In earlier stages, recurrent episodes of acute pancreatitis are the major signs dominating clinical presentation. As the inflammatory process goes on, less acute episodes occur and pain adopts different aspects or may even disappear. After 10-15 years from onset, functional insufficiency occurs. Then, a classic presentation with pain and pancreatic exocrine and endocrine insufficiency appears. Diagnosis remains challenging in the early stages of the disease, as its initial presentation is usually illdefined and overlaps with other digestive disorders. CT and MRCP should be the first choice in patients with suspected CP. If the results are normal or equivocal but still there is a high suspicion of $\mathrm{CP}$, the next choice should be EUS, with or without tissue acquisition. ERCP should be the last choice when all other imaging modalities and pancreatic function tests have been exhausted. Indirect tests may have a role in CP differential diagnosis, but their major indication is to quantify the degree of insufficiency in already-established late CP.

\section{Disclosure Statement}

All authors disclose no personal conflicts of interest or financial relationships relevant to this publication.

\section{Funding Sources}

This study has not received any funding.

\section{Author Contributions}

Richard Azevedo and Ana Caldeira were responsible for literature review regarding etiology, natural history, and diagnosis; Teresa Antunes and Joana Rita Carvalho were responsible for literature review regarding clinical diagnosis and functional tests; João Bruno Soares and Pedro Oliveira were responsible for literature review regarding imaging modalities; Vítor Magno-Pereira and Pedro Moutinho-Ribeiro were responsible for literature review regarding medical treatment; Rodrigo Liberal and Eduardo Rodrigues-Pinto were responsible for literature review regarding endoscopic treatment; Tiago Bouça Machado and José Costa-Maia were responsible for literature review regarding surgical treatment. Results were discussed in two meetings of Clube Português do Pâncreas and approved by all members. All authors critically reviewed and approved the final manuscript.

\section{References}

1 Kleeff J, Whitcomb DC, Shimosegawa T, Esposito I, Lerch MM, Gress T, et al. Chronic pancreatitis. Nat Rev Dis Primers. 2017 Sep;3: 17060.

2 Yadav D, Lowenfels AB. The epidemiology of pancreatitis and pancreatic cancer. Gastroenterology. 2013 Jun;144(6):1252-61.

3 Majumder S, Chari ST. Chronic pancreatitis. Lancet. 2016 May;387(10031):1957-66.

4 Forsmark C. Chronic Pancreatitis. In: Feldman M, Friedman L, Brandt L, editors. Sleisenger and Fordtran's Gastrointestinal and Liver Disease. Amsterdam, Elsevier Health Sciences; 2015. p. 994-1026.

5 Yadav D, Timmons L, Benson JT, Dierkhising RA, Chari ST. Incidence, prevalence, and survival of chronic pancreatitis: a populationbased study. Am J Gastroenterol. 2011 Dec; 106(12):2192-9.

6 Lévy P, Barthet M, Mollard BR, Amouretti M, Marion-Audibert AM, Dyard F. Estimation of the prevalence and incidence of chronic pancreatitis and its complications. Gastroenterol Clin Biol. 2006 Jun-Jul;30(6-7):838-44.

7 Brock C, Nielsen LM, Lelic D, Drewes AM. Pathophysiology of chronic pancreatitis. World J Gastroenterol. 2013 Nov; 19(42): 7231-40.
8 Apte M, Pirola RC, Wilson JS. Pancreatic stellate cell: physiologic role, role in fibrosis and cancer. Curr Opin Gastroenterol. 2015 Sep; 31(5):416-23.

9 Stevens T, Conwell DL, Zuccaro G. Pathogenesis of chronic pancreatitis: an evidencebased review of past theories and recent developments. Am J Gastroenterol. 2004 Nov; 99(11):2256-70.

10 Maisonneuve P, Lowenfels AB, Müllhaupt B, Cavallini G, Lankisch PG, Andersen JR, et al. Cigarette smoking accelerates progression of alcoholic chronic pancreatitis. Gut. 2005 Apr; 54(4):510-4.

11 Braganza JM, Lee SH, McCloy RF, McMahon MJ. Chronic pancreatitis. Lancet. 2011 Apr; 377(9772):1184-97.

12 Lévy P, Domínguez-Muñoz E, Imrie C, Löhr M, Maisonneuve P. Epidemiology of chronic pancreatitis: burden of the disease and consequences. United European Gastroenterol J. 2014 Oct;2(5):345-54.

13 Issa Y, Kempeneers MA, van Santvoort HC, Bollen TL, Bipat S, Boermeester MA. Diagnostic performance of imaging modalities in chronic pancreatitis: a systematic review and meta-analysis. Eur Radiol. 2017 Sep;27(9): 3820-44.
14 Ammann RW. Diagnosis and management of chronic pancreatitis: current knowledge. Swiss Med Wkly. 2006 Mar;136(11-12):166-74.

15 DiMagno MJ, Dimagno EP. Chronic pancreatitis. Curr Opin Gastroenterol. 2006 Sep; 22(5):487-97.

16 Ammann RW, Muellhaupt B. The natural history of pain in alcoholic chronic pancreatitis. Gastroenterology. 1999 May; 116(5): 1132-40.

17 Keller J, Layer P. Human pancreatic exocrine response to nutrients in health and disease. Gut. 2005 Jul;54 Suppl 6:vi1-28.

18 Carrière F, Grandval P, Gregory PC, Renou C, Henniges F, Sander-Struckmeier S, et al. Does the pancreas really produce much more lipase than required for fat digestion? JOP. 2005 May;6(3):206-15.

19 Layer P, Keller J, Intestinal Transit of Chyme and its Regulatory Role: Clinical Implications. In: Pancreatic Disease. Berlin: Springer; 1999. https://doi.org/10.1007/978-3-642-600685_11.

20 Toouli J, Biankin AV, Oliver MR, Pearce CB, Wilson JS, Wray NH; Australasian Pancreatic Club. Management of pancreatic exocrine insufficiency: Australasian Pancreatic Club recommendations. Med J Aust. 2010 Oct;193(8): 461-7. 
21 Gullo L, Tassoni U, Mazzoni G, Stefanini F. Increased prevalence of aortic calcification in chronic pancreatitis. Am J Gastroenterol. 1996 Apr;91(4):759-61.

22 Sikkens EC, Cahen DL, Kuipers EJ, Bruno MJ. Pancreatic enzyme replacement therapy in chronic pancreatitis. Best Pract Res Clin Gastroenterol. 2010 Jun;24(3):337-47.

23 Angelopoulos N, Dervenis C, Goula A, Rombopoulos G, Livadas S, Kaltsas D, et al. Endocrine pancreatic insufficiency in chronic pancreatitis. Pancreatology. 2005;5(2-3):122-31.

24 Kobayashi T, Manivel JC, Carlson AM, Bellin MD, Moran A, Freeman ML, et al. Correlation of histopathology, islet yield, and islet graft function after islet autotransplantation in chronic pancreatitis. Pancreas. 2011 Mar; 40(2):193-9.

25 Nathan JD, Zdankiewicz PD, Wang J, Spector SA, Aspelund G, Jena BP, et al. Impaired hepatocyte glucose transport protein (GLUT2) internalization in chronic pancreatitis. Pancreas. 2001 Mar;22(2):172-8.

26 Moran A, Becker D, Casella SJ, Gottlieb PA, Kirkman MS, Marshall BC, et al.; CFRD Consensus Conference Committee. Epidemiology, pathophysiology, and prognostic implications of cystic fibrosis-related diabetes: a technical review. Diabetes Care. 2010 Dec;33(12): 2677-83.

27 Lankisch PG. Function tests in the diagnosis of chronic pancreatitis. Critical evaluation. Int J Pancreatol. 1993 Aug;14(1):9-20.

$28 \mathrm{Wu} \mathrm{B}$, Conwell DL. The endoscopic pancreatic function test. Am J Gastroenterol. 2009 Oct;104(10):2381-3.

29 Nikfarjam M, Wilson JS, Smith RC; Australasian Pancreatic Club Pancreatic Enzyme Replacement Therapy Guidelines Working Group. Diagnosis and management of pancreatic exocrine insufficiency. Med J Aust. 2017 Aug;207(4):161-5.

30 Lieb JG 2nd, Draganov PV. Pancreatic function testing: here to stay for the 21st century. World J Gastroenterol. 2008 May; 14(20): 3149-58.
31 Conwell DL, Lee LS, Yadav D, Longnecker DS, Miller FH, Mortele KJ, et al. American Pancreatic Association Practice Guidelines in Chronic Pancreatitis: evidence-based report on diagnostic guidelines. Pancreas. 2014 Nov; 43(8):1143-62.

32 Durie PR, Forstner GG, Gaskin KJ, Moore DJ, Cleghorn GJ, Wong SS, et al. Age-related alterations of immunoreactive pancreatic cationic trypsinogen in sera from cystic fibrosis patients with and without pancreatic insufficiency. Pediatr Res. 1986 Mar;20(3):209-13.

33 Roberts IM, Poturich C, Wald A. Utility of fecal fat concentrations as screening test in pancreatic insufficiency. Dig Dis Sci. 1986 Oct; 31(10):1021-4.

34 Stein J, Jung M, Sziegoleit A, Zeuzem S, Caspary WF, Lembcke B. Immunoreactive elastase I: clinical evaluation of a new noninvasive test of pancreatic function. Clin Chem. 1996 Feb;42(2):222-6.

35 Hahn JU, Bochnig S, Kerner W, Koenig H, Sporleder B, Lankisch PG, et al. A new fecal elastase 1 test using polyclonal antibodies for the detection of exocrine pancreatic insufficiency. Pancreas. 2005 Mar;30(2):189-91.

36 Domínguez-Muñoz JE, Iglesias-García J, Vilariño-Insua M, Iglesias-Rey M. 13C-mixed triglyceride breath test to assess oral enzyme substitution therapy in patients with chronic pancreatitis. Clin Gastroenterol Hepatol. 2007 Apr;5(4):484-8.

37 Anaizi A, Hart PA, Conwell DL. Diagnosing Chronic Pancreatitis. Dig Dis Sci. 2017 Jul; 62(7):1713-20.

38 Frulloni L, Falconi M, Gabbrielli A, Gaia E, Graziani R, Pezzilli R, et al.; Italian Association for the Study of the Pancreas (AISP). Italian consensus guidelines for chronic pancreatitis. Dig Liver Dis. 2010 Nov;42 Suppl 6:S381-406.

39 Löhr JM, Dominguez-Munoz E, Rosendahl J, Besselink M, Mayerle J, Lerch MM, et al.; HaPanEU/UEG Working Group. United European Gastroenterology evidence-based guidelines for the diagnosis and therapy of chronic pancreatitis (HaPanEU). United European Gastroenterol J. 2017 Mar;5(2):15399.
40 Sanyal R, Stevens T, Novak E, Veniero JC. Secretin-enhanced MRCP: review of technique and application with proposal for quantification of exocrine function. AJR Am J Roentgenol. 2012 Jan;198(1):124-32.

41 Hellerhoff KJ, Helmberger H 3rd, Rösch T, Settles MR, Link TM, Rummeny EJ. Dynamic MR pancreatography after secretin administration: image quality and diagnostic accuracy. AJR Am J Roentgenol. 2002 Jul;179(1): 121-9.

42 Coakley FV, Hanley-Knutson K, Mongan J, Barajas R, Bucknor M, Qayyum A. Pancreatic imaging mimics: part 1 , imaging mimics of pancreatic adenocarcinoma. AJR Am J Roentgenol. 2012 Aug;199(2):301-8.

43 Wallace MB, Hawes RH, Durkalski V, Chak A, Mallery S, Catalano MF, et al. The reliability of EUS for the diagnosis of chronic pancreatitis: interobserver agreement among experienced endosonographers. Gastrointest Endosc. 2001 Mar;53(3):294-9.

44 Hoffmeister A, Mayerle J, Beglinger C, Büchler MW, Bufler P, Dathe K, et al.; members of the guideline committee. English language version of the S3-consensus guidelines on chronic pancreatitis: Definition, aetiology, diagnostic examinations, medical, endoscopic and surgical management of chronic pancreatitis. Z Gastroenterol. 2015 Dec;53(12): 1447-95.

45 Varadarajulu S, Eltoum I, Tamhane A, Eloubeidi MA. Histopathologic correlates of noncalcific chronic pancreatitis by EUS: a prospective tissue characterization study. Gastrointest Endosc. 2007 Sep;66(3):501-9.

46 Catalano MF, Sahai A, Levy M, Romagnuolo J, Wiersema M, Brugge W, et al. EUS-based criteria for the diagnosis of chronic pancreatitis: the Rosemont classification. Gastrointest Endosc. 2009 Jun;69(7):1251-61.

47 Mei M, Ni J, Liu D, Jin P, Sun L. EUS elastography for diagnosis of solid pancreatic masses: a meta-analysis. Gastrointest Endosc. 2013 Apr;77(4):578-89.

48 Gong TT, Hu DM, Zhu Q. Contrast-enhanced EUS for differential diagnosis of pancreatic mass lesions: a meta-analysis. Gastrointest Endosc. 2012 Aug;76(2):301-9. 